\title{
Influence of service quality, loyalty programme and perceived value on word-of-mouth behavior of domestic and international airline passengers in India
}

\author{
Joemon Pappachan
}

\author{
Aviation Academy, Cochin International Aviation Services Limited, Cochin, India \\ and Cochin University of Science and Technology, Cochin, India
}

\begin{abstract}
Purpose - This paper aims to investigate the combined effect of airline service quality (ASQ), loyalty programme and perceived value (PV) on word-of-mouth (WOM) behavior of passengers' traveling to domestic and international destinations from India.

Design/methodology/approach - Passenger's perception on service quality, loyalty programme and PV varies with flight type, which can affect WOM. This study was designed to know whether destination based difference in passengers' perception on airline services affects their WOM. Hence, a sample of 554 frequent passengers was taken, which includes 358 domestic and 196 international passengers. The responses were collected using well-structured questionnaire. The hypothetical model was developed and tested using structural equation modeling using analysis of a moment structures (AMOS).

Findings - Travel destination (flight) type moderates significantly the effect of ASQ on WOM behavior. ASQ affects WOM behavior more in domestic passengers. PV and loyalty programme do not moderate significantly with respect to destination type. PV was found to have significant influence on international passengers. However, loyalty programme was significant among domestic passengers.

Practical implications - Airline managers can develop appropriate marketing strategies targeting the passenger influencing attributes. ASQ is the most significant attribute applicable to both flight types. The airlines can focus on attractive ticket fares for international passengers and more loyalty programme benefits for domestic passengers.

Originality/value - This study examined the combined effect of ASQ, loyalty programme and PV on WOM behavior of passengers traveling in domestic and international sectors, which has not been researched yet.
\end{abstract}

Keywords Service quality, Perceived value, Word-of-mouth, Airline, Travel tourism,

Airline loyalty program

Paper type Research paper

(C) Joemon Pappachan. Published in Vilakshan - XIMB Journal of Management. Published by Emerald Publishing Limited. This article is published under the Creative Commons Attribution (CC BY 4.0) licence. Anyone may reproduce, distribute, translate and create derivative works of this article (for both commercial and non-commercial purposes), subject to full attribution to the original publication and authors. The full terms of this licence maybe seen at http://creativecommons.org/ licences/by/4.0/legalcode

Dr Binsy Mathew, Assistant Professor, Dept. of VPH, CVAS, Mannuthy, Thrissur Kerala, India.

Influence of service quality

Received 4 February 2021 Revised 16 June 2021 29 June 2021

11 September 2021 Accepted 25 October 2021 


\section{Introduction}

Airline companies are in the process of setting up an arena for a new normal situation after COVID-19 crisis. Airlines can think of ample revenue only if passengers are confident and willing to make air travel during and after the pandemic situation. Because there are travel restrictions in this pandemic time, the demand for travel is reduced and people hesitate to travel by means of public transport.

As the duration of this pandemic together with the subsequent mutation of the virus in the future is highly uncertain, the authorities are likely to put harder conditions of social distancing (Wu et al., 2020)

Tourism and aviation are interconnected because a significant portion of international passengers travel for leisure purpose. According to Abbas et al. (2021), the COVID-19 pandemic has affected the travel and tourism sector in Europe very severely; about 50\% decline in tourist arrivals was reported. Apart from damaging the economy and global health, this pandemic has triggered fear of risks among tourists, which forced them to cancel all preset travel plans. The tourists fear the vulnerability to virus infection during the time of travel (Mamirkulova et al., 2020). In the present scenario, the spreading of the virus among communities and destinations are generally caused by air passengers and tourists, and the only solution to this lethal virus is effective vaccination (Su et al., 2021).

Once the gross domestic product (GDP) of the nation improves after the pandemic, the demand for air travel will also increase. Pappachan and Koshy (2018) established this in their study that air passenger demand particularly in the domestic sector is significantly affected by the growth in GDP of a country. It is expected that there will be increase in leisure trips when compared with business travel once the pandemic subsides (Bouwer et al., 2021).

It is a known fact that a patronage buying motive can induce passengers to say good words about their preferred airline. The attributes that derive this patronage are the quality of service received from the airline, the value perceived from air travel experience and the loyalty programme attributes particularly the travel benefits enjoyed through the programme (Sandada and Matibiri, 2016). However, the combined effect of these variables on the word-of-mouth (WOM) behavior of air passengers has not yet been researched.

Though the airline ticket price being constant on a particular day, the value perceived by the passengers on the ticket fare may differ (Waring, 2006); this may affect the WOM. When passengers decide to travel on a particular sector, they may have value perceptions on the deliverance part of service quality (Szczepańska and Gawron, 2011) and also toward various offers given by the airline. So, the perceived value (PV), airline service quality (ASQ) and frequent flyer programme (FFP) were selected as independent variables, and the combined effect of these variables on the WOM of passengers as dependent variable.

\section{Theoretical background}

The WOM of passengers as a dependent variable in this study is operationally taken only up to behavioral intention. Actual behavior of passengers would be highly correlated with this intention as envisaged in the theory of planned behavior (TPB) (Ajzen, 1991). The TPB is an extension of the theory of reasoned action (TRA). The TPB has been extensively used to predict the behavior, which also includes behavior related to the travel mode. According to the TPB, behavioral intention (in this study, WOM) is determined by three antecedent factors: attitude toward the behavior, subjective norm pertaining to the behavior and perceived behavioral control. In the reformulation of this theory, Ajzen (2012) contented that a favorable attitude and a supportive subjective norm provide the motivation to engage in the intention behavior. However, a concrete intention to do so is formed only when perceived control over the behavior is significant. 
In the present study, the constructs resembling to the variables of TPB are the passengers' attitude with ASQ for attitude toward behavior, FFP for supportive subjective norm and PV for the perceived behavioral control. According to Ajzen (1991), "perceived behavioral control" is defined as people's perceptions of their ability to perform a given behavior, which is a third determinant of intention.

The review of literature related to the antecedent variables and WOM are given below.

\subsection{Airline service quality}

The success of airline depends upon the quality of service provided by it in tune with the value for money (Rajaguru, 2016). According to Kim et al. (2013), destination image would influence service quality perceptions and PV. ASQ has basically three facets (Park et al., 2020), first being those attributes connected to the "preflight operations" that include customer experiences right from ticket reservations till passengers' board into the aircraft (Chen and Chang, 2005; Park, 2007). Second facet starts from the point where passengers are boarded (Ali et al., 2016; Han, 2013) till the plane lands at the destination airport, which can be referred to as "in-flight" services (Han and Sean, 2017). Thirdly, post flight operations that cover all customer interactions after arriving at the destination airport.

\subsection{Airline frequent flyer programme}

Airline FFP also known as loyalty programme has two performance dimensions (Pappachan, 2020): first one with loyalty programme's structure-specific attributes and the second with programme FFP service-specific attributes. FFP is an airline loyalty programme that rewards passengers for their repeated purchases of the airlines' services.

As endorsed in the airline literature, customers who are highly loyal to the company are likely to be attracted by the loyalty programme of the company (Dowling and Uncles, 1997; Kim et al., 2001). This behavior of passengers was reconfirmed by studies in the Indian context, as passengers who are beginners with loyalty programme have some attraction toward the loyalty programme and thereby cause a positive WOM behavior (Pappachan, 2018).

\subsection{Perceived value}

PV of an airline can be referred to as the overall benefits perceived by the passengers through various airline services over the cost incurred by them in terms of their time, effort and money spent on receiving such services. If passengers perceive higher benefits than their effort and cost, then a positive WOM can be expected. The role of PV is contented in the literature (Cronin et al., 2000), as it can be a superior predictor of WOM behavior than customer satisfaction and service quality.

While looking into the interrelationship between service quality and PV, there are studies that claim that service quality and customer's PV have significant and positive effect on WOM behavior (Yang et al., 2012). Customers' intention to buy and their willingness to recommend the brand are influenced by a direct, positive effect of customers' perception of service quality (Boulding et al., 1993). Price and its value perception always play a significant role in passenger satisfaction and WOM (Mikulic and Darko, 2011).

\subsection{Word-of-mouth}

Passengers' WOM can be articulated as a self-motivated behavior of passengers to express their views and travel experiences of an airline to any prospective customer. It is also decreed in the literature that higher levels of service quality influences positive behavioral intentions such as "willingness to recommend the airline." This has been taken as indicators
Influence of service quality 
of WOM behavior in various studies (Bigne et al., 2001; Boulding et al., 1993; Cronin and Taylor, 1992).

Liu and Lee (2016) proved that WOM behavior of airline passengers is associated with service quality and price perception of service. They proposed that service quality can be related to increased price perception of service as a consequence of positive WOM of passengers; however, their study was based on low-cost airlines that focused only on price and service quality relationship.

WOM would be certainly affected by many variables; nevertheless, this study focuses only on the direct effect of PV, loyalty programme and service quality on WOM behavior of airline frequent passengers. The joined effect of loyalty programme, PV and service quality on WOM in a single frame work is not yet researched extensively. A hypothetical model showing the interrelationships among the independent variables on WOM behavior and the moderation effect of travel sector (flight type) is depicted in Figure 1.

\section{Hypotheses}

This study formulates the following hypotheses:

H1. There is a significant effect of perceived value on WOM behavior of passengers.

H2. There is a significant effect of loyalty programme on WOM behavior of passengers.

H3. There is a significant effect of airline service quality on WOM behavior of passengers.

H4. There is a moderation effect of travel country sector (flight type) on the relationship among the variables: (a) perceived value, (b) loyalty programme and (c) service quality on WOM.

\section{Materials and methods}

This study was conducted based on the data collected from passengers traveling within India and abroad. The primary data was collected directly from the airport departure areas after identifying frequent travelers and by using a well-structured questionnaire.

A survey among 600 frequent flyer passengers was conducted who possessed FFP, and 554 completed responses were found to be valid and used for this study. Out of 554 passengers, 358 respondents were traveling by domestic flights that are of Indian carriers and remaining 196 respondents were traveling abroad mainly to Asia-Pacific region and Middle East through international carriers.

A hypothetical model was developed and tested with AMOS software that would predict the effect of variables on passengers' WOM behavior. The effect of moderation was assessed

Figure 1.

Hypothetical model

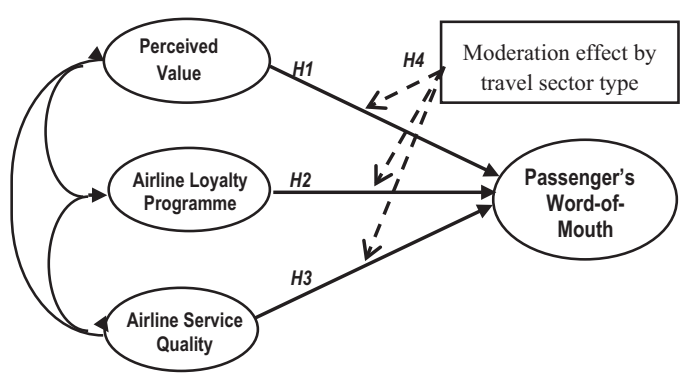


based on the difference in critical ratio values obtained for two groups. Excel statistics were used for comparing the regression weights and $P$-values, and the $Z$ scores obtained were taken for assessing the degree of moderation effect.

\subsection{Validation of scale items and measurement models}

Scale items to measure the variables were adapted from the literature, and the reliability cum validity of the instruments was confirmed using appropriate tests. Discriminant and convergent validity of the constructs under study was tested using partial least squares methods. The values of composite reliability (CR), average variance extracted (AVE), were computed. Convergent validity was confirmed, as all the $\mathrm{CR}$ values were above the acceptance thresholds levels of 0.7, which was greater than AVE values, provided all AVE values were greater than 0.5 .

The discriminant validity of the constructs was also measured using partial least squares methods, and the heterotrait-monotrait ratio of correlations method used for assessing the discriminant validity. Because all the values are less than the threshold level of 0.85 , the constructs used in this study demonstrate discriminant validity.

Measurement model for ASQ was tested with confirmatory factor analysis using AMOS software. Model fit indices and values are shown in Figure 2.

All the fit indices values confirm the measurement model of ASQ with three specific dimensions. These three dimensions altogether contain nine indicative items (Pappachan and Koshy, 2014) that are tested and reconfirmed in this study. The indicative items that reflect $\mathrm{ASQ}$ are given as follows:

- ASQ1: feel safe transactions with crew, airline staff gives exact answers, flight attendant's good manner and provide services as promised;

- ASQ2: sufficient flight schedules and sufficient connecting network; and

- ASQ3: in-flight food and beverage is good, plane seats and comforts are good and adequate entertainment facilities.

Similarly, the measurement model depicting the two dimensions of airline loyalty programme (Pappachan, 2020) were tested and reconfirmed using AMOS software, and the fit indices values are shown below (Figure 3).

As evident from the observed fit indices values, the measurement models FFP1 and FFP2 for airline loyalty programme were tested and reconfirmed with two specific dimensions. The items that reflect the construct airline FFP are given as follows:

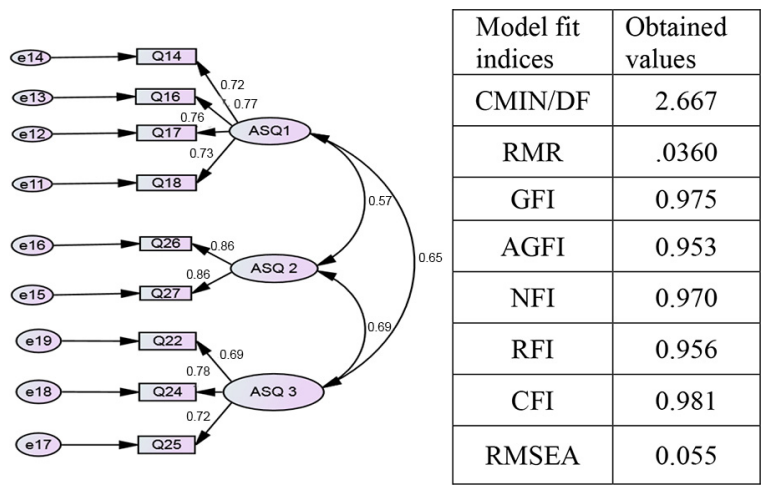

Influence of service quality 
- FFP1: priority in baggage and check In, easiness in obtaining preferred seat, treats FFP members better than others and better facilities in lounges and in flights and

- FFP2: easy and flexible to redeem benefits, flexible duration/validity of FFP, efficiency of updating FFP status and FFP status makes passenger feel special.

"PV" construct was measured using items in the available literature Chen (2008) as follows:

- Considering the ticket price, I pay for the airline, I believe that the airline offers sufficient services.

- The ticket price of this airline is reasonable.

- I think this airline prices are competitive,

The WOM variable was taken as the dependent variable that was measured using the scale items available from previous studies (Zhang and Bloemer, 2008) is given as follows:

- I will recommend this airline to other people.

- I say positive things about this airline services to other people.

- I will continue patronizing this airline.

- I recommend this airline's loyalty programme to others.

\section{Results and findings}

All measurement models and the latent constructs were put in the structural equation modeling (SEM), and fit indices values were taken for analysis. The result indicates that the combined model (two sectors together) was found valid, and the model fit indices were within the acceptable levels. The model fit indices goodness of fit index (GFI), normed fit index (NFI), relative fit index (RFI), incremental fit index (IFI), tucker- lews index (TLI) and comparative fit index (CFI) showed values above 0.9 which indicates good fit. Similarly, root mean square residual (RMR) and root mean square error of approximation (RMSEA) values were found to be less than 0.06 . Moreover, the chi -square minimum/ degrees of freedom (CMIN/DF) value was also found to be less than 2 which all indicates statistical validity of the hypothetical model (Figure 4).

The effects of ASQ, PV and FFP on WOM are estimated with the regression weights by using SEM. Regression weights of the variables are predicted using maximum likelihood estimates method, and the values are found to be significant as the $P$-values were less than 0.1. It was observed that all the latent constructs of FFP and ASQ were well estimated, and

Figure 3.

Measurement model for FFP and model fit indices

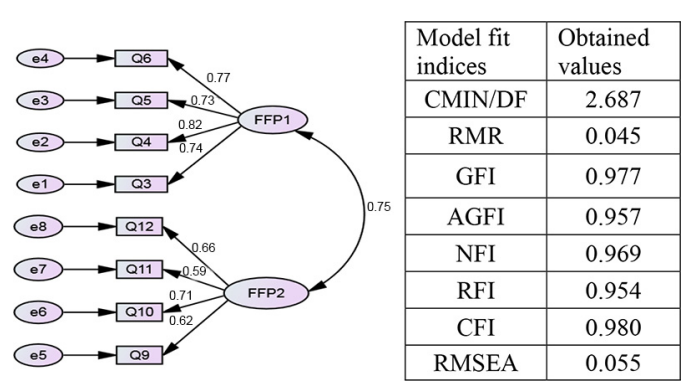




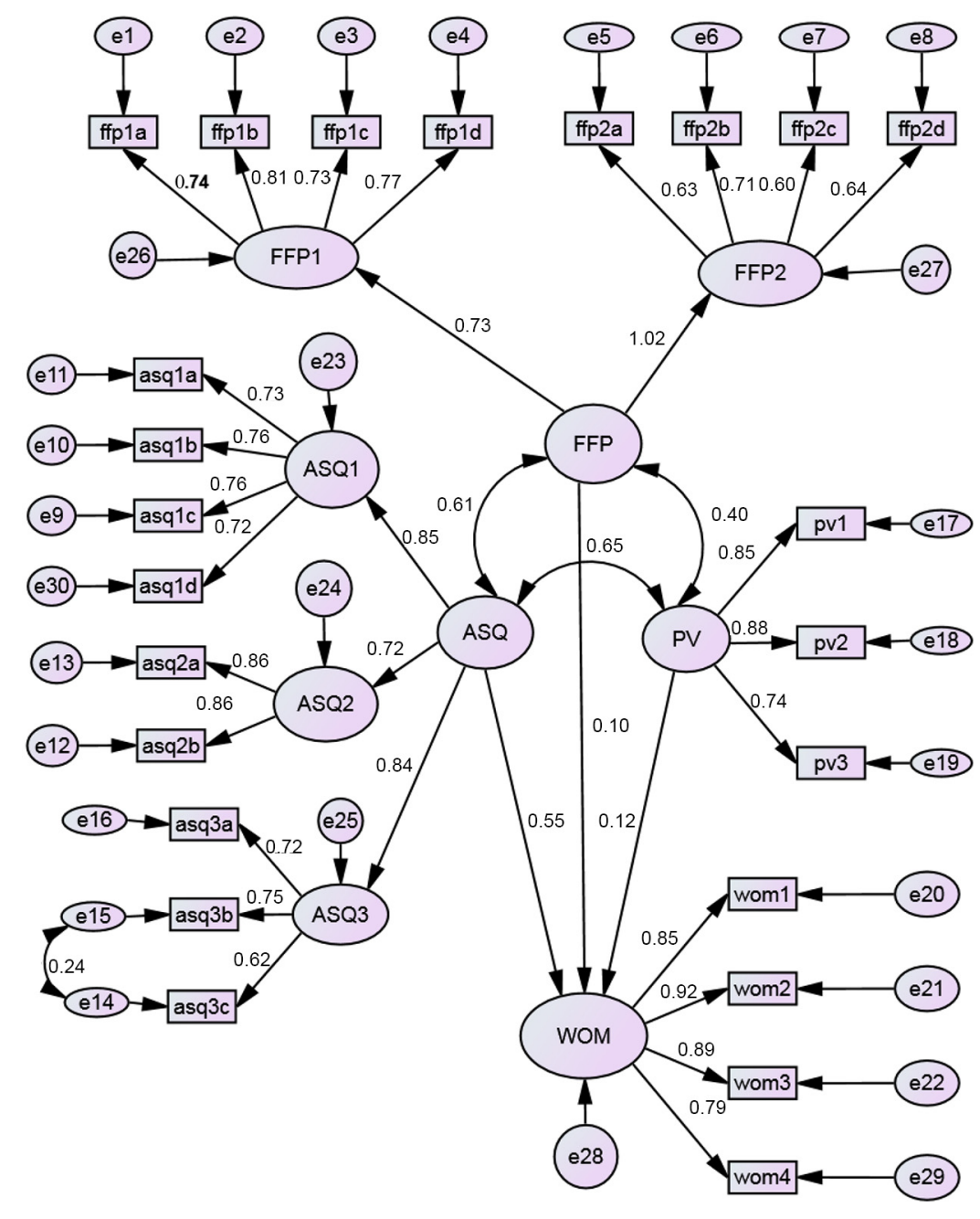

Influence of service quality

Figure 4 . Structural equation model (international and domestic sectors)

the corresponding $P$-value demonstrates significant results. The three variables, namely, ASQ, PV and FFP, were structured as independent variables in the SEM model, and the effect of these variables in predicting WOM intention behavior of passengers were tested. Only ASQ influenced significantly $(P$-value $<0.01)$. The type of flight, namely, domestic and international passenger groups, was separately analyzed using the subgroup models and regression estimates for each were taken (Table 1).

It was observed that among the domestic passengers' category ASQ explained WOM significantly, whereas FFP showed slight effect on WOM ( $P$-value significant at $5 \%$ ), and PV did not explain WOM significantly. Similarly, in the international passengers' category, ASQ significantly explained WOM, whereas PV showed slight effect on WOM ( $P$-value significant at $5 \%$ ); however, FFP did not significantly explain WOM. 


\subsection{Test of moderation}

To verify the effect of moderation caused by travel sector type, pair-wise difference in critical ratios and estimates of regression values on the paths between the variables ASQ, FFP, PV and WOM were compared using AMOS. There was variation in regression estimates between the two groups represented by the travel flight type as seen in the two sub models; the $P$-values for PV and FFP were found to be fluctuating based on travel sector (flight type). The difference in $P$-values obtained were also further tested using excel statistics, and $Z$-score values were taken and compared for testing the moderation effect.

Moderation effect was observed and found significant with ASQ. Though the $Z$ score was found to be less than 1.96 yet greater than 1.645, it indicates slight moderation effect because of flight type on the link between ASQ and WOM. Because the $Z$-score value for PV and FFP was between -1.645 and +1.645 range, the effect of moderation because of travel country-specific type on the paths between PV and WOM; FFP and WOM were not significant.

\section{Discussion}

ASQ significantly influences WOM behavior of passengers irrespective of the type of flight, as found in this study, which is in accordance with the TPB (Ajzen, 2012). The finding of this study is similar to other studies, which proclaim that passengers' choice of an airline is based on the quality of airline services (Espino et al., 2008; Hess et al., 2007). It was observed in this study that loyalty programme had no significant effect on creating WOM among the international sector passengers; however, it had modest impact on the domestic sector passengers. This is supported by the recent findings of Bouwer et al. (2021) that predict better recovery of domestic flight type in the post pandemic time. Shah et al. (2020) revealed that flight category is a significant variable for measuring passenger perception and satisfaction. Their results demonstrated that both the domestic and international passengers perceive the service quality equally important, which was also found valid in this study. PV derived positive WOM in the present study, which is consistent in the findings of Cronin et al. (2000).

Even though the ticket fares are relatively high in international sector as compared to domestic sector, the PV had some effect or control in the international passengers' behavioral intention. Consequently, passengers would be naturally choosing an airline that offers quality services at the best price. On the contrary, in the domestic sector, majority of the business passengers' travel are sponsored by the firms they work with. Therefore, domestic passengers' WOM may not get influenced largely by PV. This is in agreement with the special case ascribed to the TPB (Ajzen, 2012), as the TPB reduces to TRA when people have perfect volitional control over the behavior of interest. Hence, this study reinforces the special case of TPB that the behavioral control becomes irrelevant when people strongly believe that they are capable of performing the behavior.

Table 1.

Comparison of SEM output results of domestic and international sectors

\begin{tabular}{|c|c|c|c|c|c|c|c|c|c|c|}
\hline \multirow{2}{*}{\multicolumn{3}{|c|}{ Effect between constructs }} & \multicolumn{4}{|c|}{ Domestic flight passenger sector } & \multicolumn{4}{|c|}{ International flight passenger sector } \\
\hline & & & Estimate & SE & $\mathrm{CR}$ & $P$-value & Estimate & $\mathrm{SE}$ & $\mathrm{CR}$ & $P$-value \\
\hline WOM & $\leftarrow$ & ASQ & 1.168 & 0.24 & 4.876 & $* * *$ & 0.649 & 0.173 & 3.76 & **** \\
\hline WOM & $\leftarrow$ & PV & 0.05 & 0.07 & 0.706 & 0.48 & 0.167 & 0.072 & 2.31 & $0.021 * *$ \\
\hline WOM & $\leftarrow$ & FFP & 0.157 & 0.067 & 2.343 & $0.019 * *$ & -0.082 & 0.14 & -0.588 & 0.557 \\
\hline
\end{tabular}

Notes: $* * * P$-value $<0.01 ; * * P$-value $<0.05$

Source: SEM text outputs of the study 


\section{Practical implications}

As per the results obtained, FFP seems to be relatively more relevant in the domestic sector than the international sector. This could be attributed by the fact that selection of the preferred airline is more practical in domestic sector; however, passengers traveling in international sector may not bother to avail FFP benefits especially during the pandemic situation.

Therefore, it is recommended that airlines may focus more on the service quality attributes and provide world class experience in both the international and domestic sectors. Investing extra efforts on promotional programme particularly in the international sector may not be fruitful. "PV" of passengers plays a significant role in deciding the ticket fare especially in the international sector. In the domestic sector, loyalty programme may be given emphasis, as the airlines have to face more competition in this sector not only from regional or local airlines but also from other modes of travel for short-haul journeys.

\section{Contribution from the study}

This study enumerated the influence of service quality, loyalty programme and PV of airline passengers on their WOM intention. This study has given better understanding on the flight sector-wise variation on passenger preferences on FFP, PV and ASQ attributes. It was found that ASQ significantly varied with the international flight destinations. This study also contributes to the literature that loyalty programme has more importance in the domestic sector, whereas PV is more relevant in the international sector. Findings of this study would be beneficial to the airline managers to take appropriate decisions particularly during the pandemic times.

\section{Conclusion}

This study provided some vital information relating to airline passenger preferences for the air travel and in making appropriate marketing strategy by airlines. ASQ can augment the WOM intention in both the domestic and international sectors. The WOM intention was significantly influenced by PV in the domestic sector passengers and by FFP in the international sector passengers.

\section{References}

Abbas, J., Mubeen, R., Iorember, P.T., Raza, S. and Mamirkulova, G. (2021), "Exploring the impact of COVID-19 on tourism: transformational potential and implications for a sustainable recovery of the travel and leisure industry", Current Research in Behavioral Sciences, Vol. 2, doi: 10.1016/j. crbeha.2021.100033.

Ajzen, I. (1991), "The theory of planned behavior", Organizational Behavior and Human Decision Processes, Vol. 50 No. 2, pp. 179-211.

Ajzen, I. (2012), "The theory of planned behavior", in: Lange, P.A.M., Kruglanski, A.W. and Higgins, E. T. (Eds), Handbook of Theories of Social Psychology, England, Sage, Vol. 1, pp. 438-459.

Ali, F., Woo, G.K. and Ryu, K. (2016), "The effect of physical environment on passenger delight and satisfaction: moderating effect of national identity", Tourism Management, Vol. 57, pp. 213-224.

Bigne, J.E., Sanchez, M.I. and Sanchez, J. (2001), "Tourism image, evaluation variables and after purchase behaviour: inter-relationship”, Tourism Management, Vol. 22 No. 6, pp. 607-616.

Boulding, W., Kalra, A., Staelin, R. and Zeithaml, V.A. (1993), "A dynamic process model of service quality: from expectations to behavioral intentions", Journal of Marketing Research, Vol. 30 No. 1, pp. 7-27. 
Bouwer, J., Saxon, S. and Wittkamp, N. (2021), "Back to the future? Airline sector poised for change postCOVID-19", available at: www.mckinsey.com/industries/travel-logistics-and-infrastructure/ourinsights/back-to-the-future-airline-sector-poised-for-change-post-covid-19 (accessed 21 June 2021).

Chen, C.F. (2008), "Investigating structural relationships between service quality, perceived value, satisfaction, and behavioral intentions for air passengers: evidence from Taiwan", Transportation Research Part A: Policy and Practice, Vol. 42 No. 4, pp. 709-717.

Chen, F.Y. and Chang, Y.H. (2005), "Examining airline service quality from a process perspective", Journal of Air Transport Management, Vol. 11 No. 2, pp. 79-87.

Cronin, J.J., Jr, Brady, M.K. and Hult, G.T.M. (2000), "Assessing the effects of quality, value, and customer satisfaction on consumer behavioral intentions in service environments", Journal of Retailing, Vol. 76 No. 2, pp. 193-218.

Cronin, J.J., Jr and Taylor, S.A. (1992), "Measuring service quality: a reexamination and extension", Journal of Marketing, Vol. 56 No. 3, pp. 55-68.

Dowling, G.R. and Uncles, M. (1997), "Do customer loyalty programmes really work?", Sloan Management Review, Vol. 38, pp.71-82.

Espino, R., Carlos, M.J. and Román, C. (2008), "Analyzing the effect of preference heterogeneity on willingness to pay for improving service quality in an airline choice context", Transportation Research Part E: Logistics and Transportation Review, Vol. 44 No. 4, pp. 593-606.

Han, H. (2013), "Effects of in-flight ambience and space/function on air travelers' decision to select a low-cost airline", Tourism Management, Vol. 37, pp. 125-135.

Han, H. and Sean, H.S. (2017), "Impact of hotel-restaurant image and quality of physical-environment, service, and food on satisfaction and intention", International Journal of Hospitality Management, Vol. 63, pp. 82-92.

Hess, S., Adler, T. and Polak, J.W. (2007), "Modelling airport and airline choice behaviour with the use of stated preference survey data", Transportation Research Part E: Logistics and Transportation Review, Vol. 43 No. 3, pp. 221-233.

Kim, S.H., Holland, S. and Han, H.S. (2013), "A structural model for examining how destination image, perceived value, and service quality affect destination loyalty: a case study of Orlando", International Journal of Tourism Research, Vol. 15 No. 4, pp. 313-328.

Kim, B.D., Shi, M. and Srinivasan, K. (2001), "Reward programmes and tacit collusion”, Marketing Science, Vol. 20 No. 2, pp. 99-120.

Liu, C.H.S. and Lee, T. (2016), "Service quality and price perception of service: influence on word-of-mouth and revisit intention”, Journal of Air Transport Management, Vol. 52, pp. $42-54$.

Mamirkulova, G., Mi, J., Abbas, J., Mahmood, S., Mubeen, R. and Ziapour, A. (2020), "New silk road infrastructure opportunities in developing tourism environment for residents better quality of life", Global Ecology and Conservation, Vol. 24, p. e01194.

Mikulic, J. and Darko, J. (2011), "What drives passenger loyalty to traditional and low-cost airlines? A formative partial least squares approach", Journal of Air Transport Management, Vol. 17 No. 4, pp. 237-240.

Pappachan, J. (2020), “Attribute level performance dimensions of airline frequent flyer programme: a factor analysis approach", International Journal of Management and Economics Invention, Vol. 6 No. 1, pp. 2149-2159, doi: 10.33826/ijmei/v6i1.02.

Pappachan, J. (2018), "Effect of 'single' vs 'multiple' possession and usage of loyalty programme on repurchase intention behavior of airline frequent passengers in India", Journal of Airline and Airport Management, Vol. 8 No. 2, pp. 13-27.

Pappachan, J. and Koshy, M. (2014), “Attribute-level performance dimensions of airline service quality: a factor analysis approach”, Indian Journal of Marketing, Vol. 44 No. 8, pp. 7-20. 
Pappachan, J. and Koshy, M. (2018), "Effects of economic growth on the development of civil aviation market- study based on development status of selected economies", Vilakshan-XIMB Journal of Management, Vol. 15 No. 1, pp. 67-88.

Park, J.W. (2007), "Passenger perceptions of service quality: Korean and Australian case studies", Journal of Air Transport Management, Vol. 13 No. 4, pp. 238-242.

Park, S., Lee, J.S. and Nicolau, J.L. (2020), "Understanding the dynamics of the quality of airline service attributes: satisfiers and dissatisfiers", Tourism Management, Vol. 81, pp. 104-163.

Rajaguru, R. (2016), "Role of value for money and service quality on behavioural intention: a study of full service and low cost airlines", Journal of Air Transport Management, Vol. 53, pp. 114-122.

Sandada, M. and Matibiri, B. (2016), "An investigation into the impact of service quality, frequent flier programmes and safety perception on satisfaction and customer loyalty in the airline industry in Southern Africa", South East European Journal of Economics and Business, Vol. 11 No. 1.

Shah, F.T., Syed, Z., Imam, A. and Raza, A. (2020), “The impact of airline service quality on passengers' behavioral intentions using passenger satisfaction as a mediator", Journal of Air Transport Management, Vol. 85, doi: 10.1016/j.jairtraman.2020.101815.

Su, Z., McDonnell, D., Wen, J., Kozak, M., Abbas, J., Segalo, S. and Xiang, Y.T. (2021), "Mental health consequences of COVID-19 media coverage: the need for effective crisis communication practices", Globalization and Health, Vol. 17 No. 1, pp. 1-8.

Szczepańska, K. and Gawron, P.P. (2011), "Changes in approach to customer loyalty", Contemporary Economics, Vol. 5 No. 1, p. 10.

Waring, P. (2006), "Aesthetic labour, cost minimization and the labour process in the Asia pacific airline industry”, Strategic Direction, Vol. 22 No. 6.

Wu, J.T., Leung, K. and Leung, G.M. (2020), "Nowcasting and forecasting the potential domesticand international spread of the 2019-nCoV outbreak originating in Wuhan, China: a modeling study", The Lancet, Vol. 395 No. 10225, pp. 689-697.

Yang, K.C., Hsieh, T.C., Li, H. and Yang, C. (2012), "Assessing how service quality, airline image and customer value affect the intentions of passengers regarding low cost carriers", Journal of Air Transport Management, Vol. 20, pp. 52-53.

Zhang, J. and Bloemer, J.M. (2008), “The impact of value congruence on consumer-service brand relationships", Journal of Service Research, Vol. 11 No. 2, pp. 161-178.

\section{Corresponding author}

Joemon Pappachan can be contacted at: jpparavattil@gmail.com

For instructions on how to order reprints of this article, please visit our website: 